\title{
Effect of environmental factors on growth and physiological status of generative shoots of Cladium mariscus in a protected calcareous fen habitat
}

\author{
Dace Megre ${ }^{1 *}, K_{\text {Kristine Dokane }}^{1,2}$, Daina Roze ${ }^{1}$, Linda Strode ${ }^{1}$ \\ ${ }^{1}$ National Botanical Garden, Miera 1, Salaspils LV-2169, Latvia \\ ${ }^{2}$ Institute of Biology, University of Latvia, Miera 3, Salaspils LV-2169, Latvia \\ ${ }^{\star}$ Corresponding author, E-mail: dace.megre@gmail.com
}

\begin{abstract}
Effective conservation of priority habitat $7210^{\star}$ Calcareous fens with Cladium mariscus and species of the Caricion davallianae depends on complete knowledge of the biology of Cladium mariscus. This study was aimed to determine effect of temperature and habitat water level on growth, development and physiological status of generative shoots of C. mariscus. Maximum quantum yield of photosystem II photochemistry dynamics during both seasons was similar; but in summer 2016 the values were significantly higher than in 2015. Difference in height of generative shoots was not found between years. Average number of generative shoots indicated a significant difference between years. Immediate effect of temperature or habitat water level changes on generative shoot growth were not observed. However, two-season measurements of maximum quantum yield of photosystem II photochemistry showed that $C$. mariscus is welladapted to high habitat water level and might be sensitive to habitat water level fluctuations, when the water level falls below $5 \mathrm{~cm}$. On the north-eastern limit of the distribution range the number of generative shoots of C. mariscus in the next growing season is affected by previous autumn drought and temperature below $0{ }^{\circ} \mathrm{C}$ as well.
\end{abstract}

Key words: chlorophyll $a$ fluorescence, Cladium mariscus, generative shoots, temperature, water level.

\section{Introduction}

Great fen-sedge Cladium mariscus(L.) Pohlis a characteristic and dominant species of European Union priority habitat $7210^{*}$ Calcareous fens with Cladium mariscus and species of the Caricion davallianae. This habitat is one of the rarest in Latvia, and occurs sporadically in the Coastal Lowlands, Kurzeme, in Eastern Latvia, as well as in the geobotanical region of South East Latvia. Currently the area occupied by the habitat is only approximately 220 ha (Aunina 2013).

The C. mariscus sites in Latvia are located close to the north-eastern limit of the species distribution range. It is included in the specially protected and limited use species list, and in the Latvian Red Data Book, category 3 (Eglite 2003) and in the Red Data Book of the Baltic Sea Region (Kuusk et al. 2003). It is known that the distribution of $C$. mariscus in Latvia is determined by habitat availability, winter temperature and duration of the frost-free period (Salmiņa 2003; Salmina 2004).

Locally C. mariscus spreads by horizontal rhizomes forming a large number of clones spaced around the parent plants (Cronk, Fennessy 2001; Namura-Ochalska 2005). In suitable habitat and favourable environmental conditions C. mariscus establishes monodominant stands (Theocharopoulos et al. 2006). It is known that the species is sensitive to temperature (Conway 1940; Salmina 2004) and changes in hydrological conditions (Burkill 2000; Theocharopoulos et al.2006). In the eastern part of Finland and in Latvia the well-tolerated temperature range for $C$. mariscus is between -4 and $-6^{\circ} \mathrm{C}$ in the coldest month of a year and between 16 and $18{ }^{\circ} \mathrm{C}$ in the warmest month of a year (Jalas, Okko 1951; Salmina 2004). The optimal water depth for growth of $C$. mariscus is $40 \mathrm{~cm}$ above the ground surface (Buczek 2005; Vaughan 2012).

Previous studies on the species have been devoted to population dynamics (Namura-Ochalska 2005), primary productivity and biomass (Bernard et al. 1985), while little is known about the influence of the habitat water level and temperature fluctuations during the vegetation season on growth and physiological status of generative shoots of $C$. mariscus.

Non-destructive analysis of photosynthesis-related characteristics has special importance in field studies of rare and especially protected plant species (Kalaji et al. 2016). Currently chlorophyll $a$ fluorescence measurements are widely used in many physiological and ecophysiological studies (Maxwell, Johnson 2000; Kalaji et al. 2016), as they provide insight in plant primary photochemistry and in plant physiological response to both short-term and longterm changes in environmental conditions, including severe temperature changes, water and drought stress etc. The most frequently used chlorophyll $a$ fluorescence 
parameter is maximum quantum yield of photosystem II photochemistry $\left(\mathrm{F}_{\mathrm{v}} / \mathrm{F}_{\mathrm{m}}\right)$ (Kalaji et al. 2017).

The aim of the present study was to determine effect of temperature and habitat water level on growth and physiological status of generative shoots of $C$. mariscus in habitat $7210^{*}$ Calcareous fens with Cladium mariscus and species of the Caricion davallianae on the north-eastern limit of the species range.

\section{Materials and methods}

The study site was located in a topographical depression near Lake Engure in the Coastal Lowland of Latvia $\left(57^{\circ} 15.813^{\prime} \mathrm{N}, 23^{\circ} 08.659 \mathrm{E}\right)$, where C. mariscus is relatively more abundant than elsewhere in Latvia (Fig. 1). The field study was carried out from September 2014 to September 2016.

Monitoring of water level in the habitat was carried out every two weeks from June till middle of August in 2015 and 2016. A standardised ruler was used for the water level measurement. Each measurement was obtained in 10 replicates. Meteorological data (air temperature, precipitation) in 2015-2016 were obtained from the Latvian Environment, Geology and Meteorology Centre (Meteorological Station Mersrags) in the website http:// www.meteo.lv.

Moss and flowering plant species in the monitored permanent plot $\left(1200 \mathrm{~m}^{2}\right.$ in size $)$ were identified using Mossberg, Stenberg (1992) and Atherton et. al (2010). The total cover of vascular plant species was visually estimated (from 1 to 100 percent). The taxa were named in accordance with The International Plant Names Index (http://www.ipni.org/ipni/plantnamesearchpage.do) and List of Bryophytes of Latvia (Āboliņa 2001).

Height was measured for 30 randomly selected generative stems of C. mariscus, every two weeks from June till middle of August in 2015 and 2016. The measurements were taken from the submerged part of the substrate to the tip of generative shoot. During the study period the phenological stage of C. mariscus was also determined. Inventory of generative shoots was conducted in $1 \mathrm{~m}^{2}$ plots on either side of four transects in permanent plot $\left(1200 \mathrm{~m}^{2}\right.$ in size) in middle of July in 2015 and 2016.

Measurement of C. mariscus leaf chlorophyll a fluorescence was performed every two weeks from June till middle of August 2015 and 2016 using a fluorimeter PAM 2100 (Heinz Walz GmbH, Germany) on 20 min dark adapted leaves of 8 to 10 generative shoots. One current year's leaf per generative shoot was measured.

For statistical analysis GraphPad Prism for Windows (v 6.01) was used. All data were presented as a mean with standard error. $T$-tests were used to assess significant differences between years in generative shoot height, generative shoot count per $1 \mathrm{~m}^{2}$, habitat water level, average two-week temperature and chlorophyll $a$ fluorescence

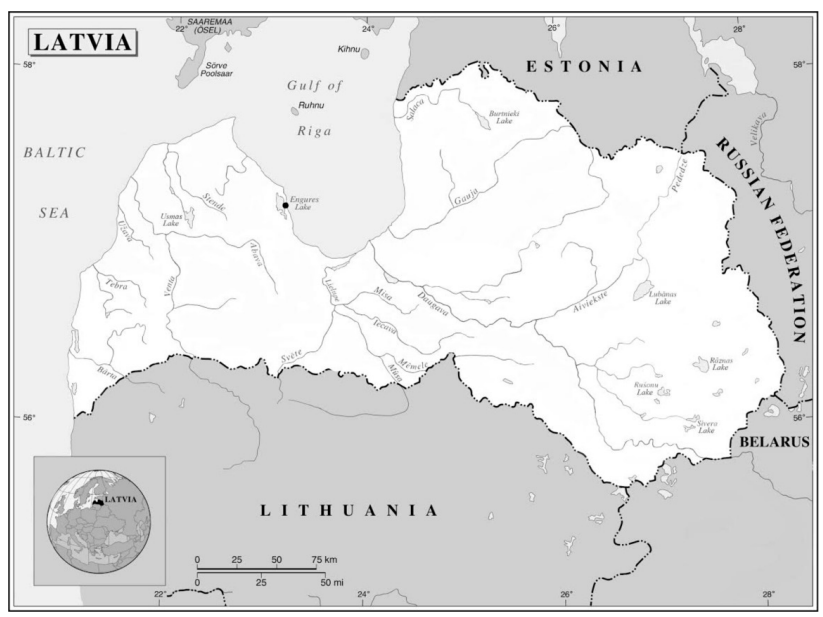

Fig. 1. Studied locality in a depression near Lake Engure in the Coastal Lowland of Latvia (base map: https://commons. wikimedia.org/wiki/File:Un-latvia.png).

parameter $\mathrm{F}_{\mathrm{v}} / \mathrm{F}_{\mathrm{m}}$. Pearson correlation coefficients between water level, average two-week temperature and chlorophyll a fluorescence as well as generative shoot height were determined.

\section{Results}

In summer 2015 there was a sharp decrease of habitat water level between week 1 and week 3 , which was followed by an increase till week 5 and a gradual decrease until week 9 (Fig. 2). The habitat fully dried out in the period from week 9 to week 11. In contrast, in summer 2016 the habitat water level was significantly higher $(p<0.05)$ throughout the summer and severe drought was not observed. Two-week average temperatures showed similar trends in summer 2015 and 2016 (Fig. 3). In general, temperature in summer 2016 was higher except for a decrease between week 1 and week 3 . There was no statistically significant difference in

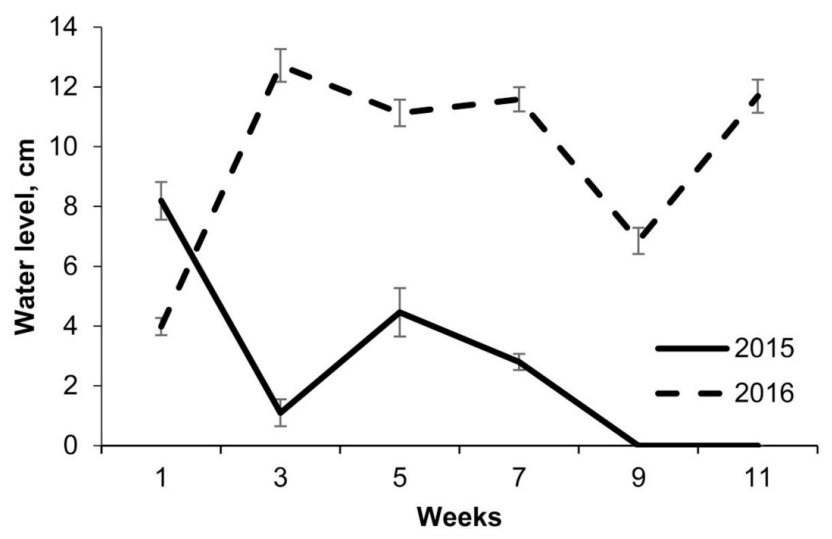

Fig. 2. Water level changes in habitat $7210^{\star}$ Calcareous fens with Cladium mariscus and species of the Caricion davallianae from June till middle of August in 2015 and 2016. 


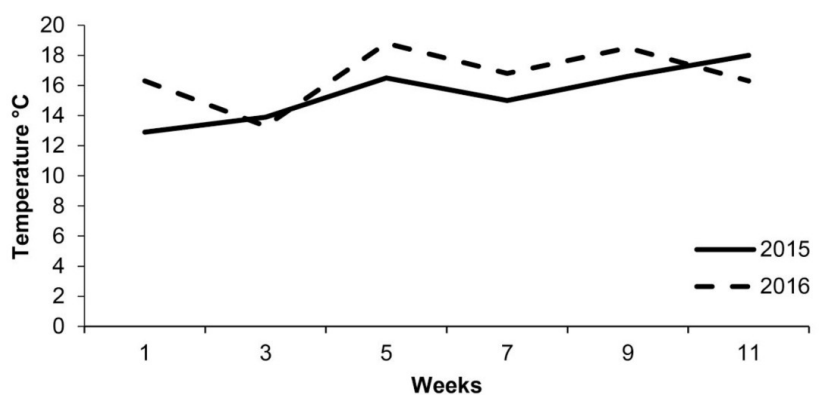

Fig. 3. Average temperature changes in habitat $7210^{*}$ Calcareous fens with Cladium mariscus and species of the Caricion davallianae from June till middle of August in 2015 and 2016.

temperature between both years.

September 2015 in Latvia was warmer than usual; the average air temperature was $13.3^{\circ} \mathrm{C}$, which was 1.6 ${ }^{\circ} \mathrm{C}$ above normal. In Mersrags in September the average air temperature was $13.6{ }^{\circ} \mathrm{C}$. In Latvia, mean September precipitation was less than usual, and the average precipitation was $66.5 \mathrm{~mm}$, which was $93 \%$ of the monthly precipitation norm. In Mersrags precipitation in this month was $39.0 \mathrm{~mm}$ (Fig. 4). October 2015 was very dry, and average precipitation in Latvia was only $8.7 \mathrm{~mm}$, which was $13 \%$ of the monthly precipitation average. October 2015 was the driest in the observation history of Latvia. In Mersrags precipitation in this month was $8.0 \mathrm{~mm}$ (Fig. 4). October was a very cool month; the average air temperature was $5.7^{\circ} \mathrm{C}$, which was $1.0^{\circ} \mathrm{C}$ below the longterm norm. In addition, many all-time low temperature records were set in October. In Mersrags on October $8\left(-0.6{ }^{\circ} \mathrm{C}\right)$ temperature fell below $0{ }^{\circ} \mathrm{C}$ for the first time in that autumn and the lowest temperature was $-7.3^{\circ} \mathrm{C}$ (October 30). In general, during October there were 12 nights in Mersrags when temperature fell below $0{ }^{\circ} \mathrm{C}$ (Fig. 4). The average air temperature in November 2015 was $3.0^{\circ} \mathrm{C}$ above normal. Precipitation was $70.3 \mathrm{~mm}$, which was $112 \%$ of the monthly precipitation norm. In Mersrags in this month the average air temperature was $5.1{ }^{\circ} \mathrm{C}$. Precipitation was $71.6 \mathrm{~mm}$ which also exceeded the monthly precipitation average (Fig. 4).

In the permanent plot $C$. mariscus grew together with vascular plants Liparis loeselii (L.) Rich., Lycopus europaeus L., Phragmites australis (Cav.) Steud., Schoenus ferrugineus L. and moss Campylium stellatum (Hedw.) J.Lange et C.Jens. The moss C. stellatum grew in hummocks of S. ferrugineus. In 2016 projective cover of vascular plants in the permanent plot was $90 \%$. C. mariscus contributed $85 \%$ of the cover and was monodominant. Other vascular plant species formed $15 \%$ of the cover, moreover cover of P. australis was 1\%.

Rapid growth of generative shoots began in the first decade of June (Fig. 5). Flowering of C. mariscus began in the third decade of June and lasted up to the second decade of July. In the third decade of July, ripening of C. mariscus seeds began. Generative shoots of $C$. mariscus reached maximum height around July 20. There was no significant difference between the final height of generative shoots in 2015 and 2016 (Fig. 5). There was no correlation between average two-week temperature or habitat water level and height of generative shoots. Average number of generative shoots per $1 \mathrm{~m}^{2}$ was $17.1 \pm 1.0$ in 2015 and $0.7 \pm 0.2$ in 2016 and the difference between the years was significant $(p<$ 0.05).

$\mathrm{F}_{\mathrm{v}} / \mathrm{F}_{\mathrm{m}}$ dynamics during both seasons were similar, but in

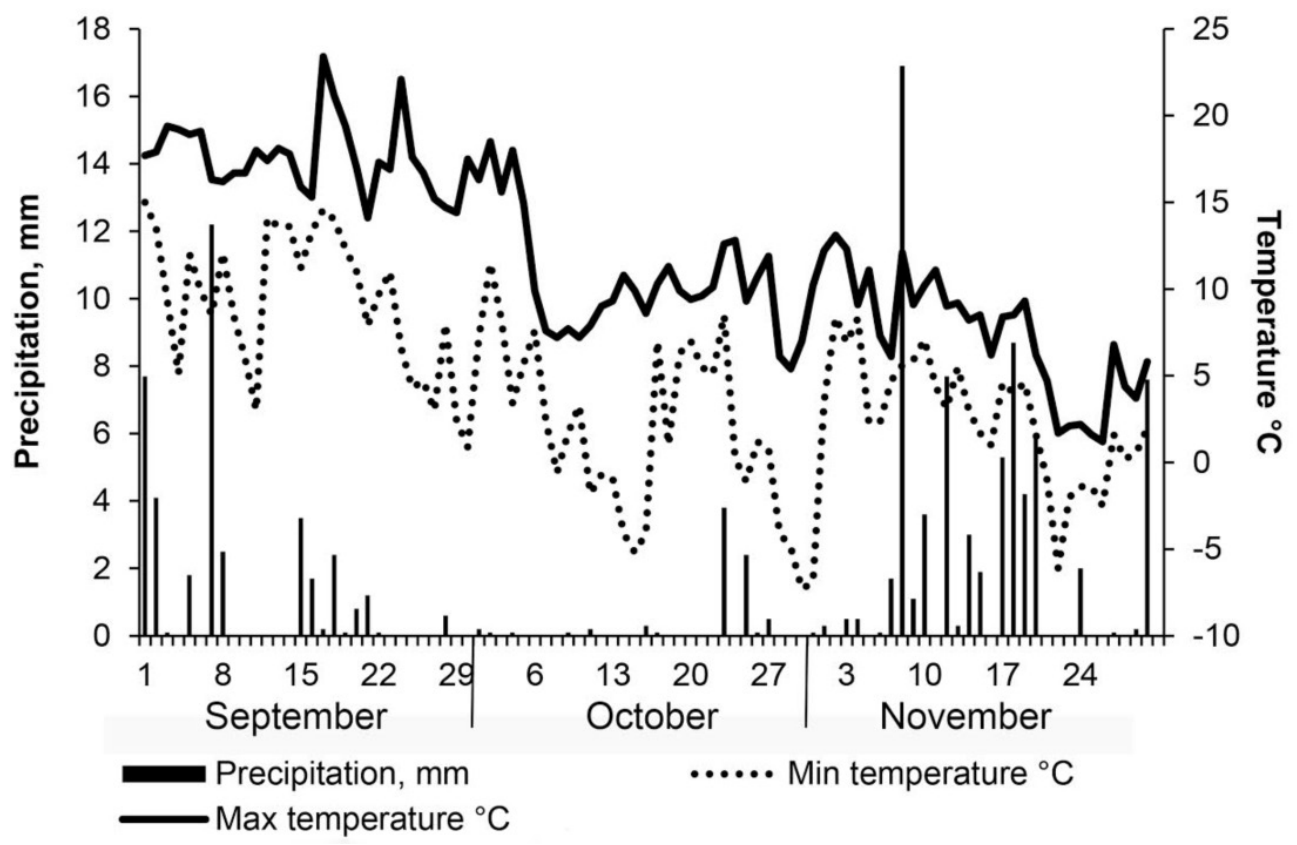

Fig. 4. Changes of daily minimum and maximum air temperature and precipitation in Meteorological Station Mersrags from September till November in 2015. 


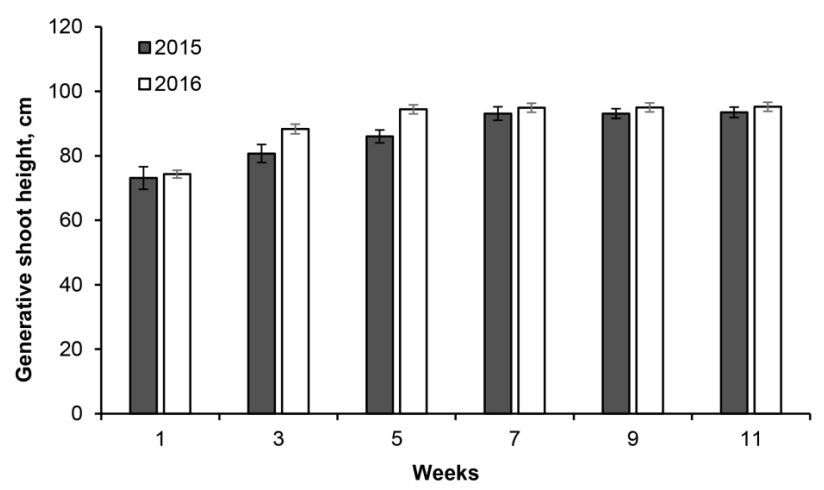

Fig. 5. Height of Cladium mariscus generative shoots in habitat $7210^{*}$ Calcareous fens with Cladium mariscus and species of the Caricion davallianae from June till middle of August in 2015 and 2016.

summer $2016 \mathrm{~F}_{\mathrm{v}} / \mathrm{F}_{\mathrm{m}}$ was significantly higher than in 2015 $(p<0.05)$. Statistical analysis of chlorophyll $a$ fluorescence values revealed that during summer 2015 and 2016, $\mathrm{F}_{\mathrm{v}} / \mathrm{F}_{\mathrm{m}}$ of C. mariscus did not change significantly, except in week 1 when it was significantly lower both in 2015 and 2016 (Fig. 6). There was no correlation between average two-week temperature or habitat water level and $\mathrm{F}_{v} / \mathrm{F}_{\mathrm{m}}$.

\section{Discussion}

If C. mariscus is tolerant to environmental factors in a habitat it can establish in a pre-existing plant community and cause changes in its composition (Theocharopoulos et al. 2006). This was the case also in the present study. In the studied site the cover of C. mariscus had increased from 15 to $70 \%$ from 2008 to 2013 (Roze et al. 2014) and in 2016 it formed $85 \%$ of the cover. Cover of P. australis decreased from 10 to $1 \%$, although the species has a broad ecological niche from dry to submerged habitats (Saltmarsh et al. 2006; Meyerson et al. 2016). Most likely this decrease was due to better ability of $C$. mariscus to adapt to low phosphorus concentrations in comparison to P. australis (Doren et al. 1997). It is known that there is a low phosphorus concentration in sediments of Lake Engure and its basin, compared to other Latvian lakes (Kḷaviņš et al. 2014). Species with relatively low competitive ability, such as Epipactis palustris L., Potentilla erecta L., Primula farinosa L. and Utricularia intermedia L., had disappeared from the site in the period before 2013 (Roze et al. 2014). Nevertheless S. ferrugineus, L. loeselii, and L. europaeus were still found in the habitat in 2016, but the number of individuals had decreased and contributed less than 15\% of the cover.

C. mariscus formed a monodominant stand consisting of both vegetative and generative shoots. It was found that generative shoots reached a height of approximately $1 \mathrm{~m}$ (Fig. 5). Such a height is low even for northern parts of the species range, and elsewhere height of C. mariscus

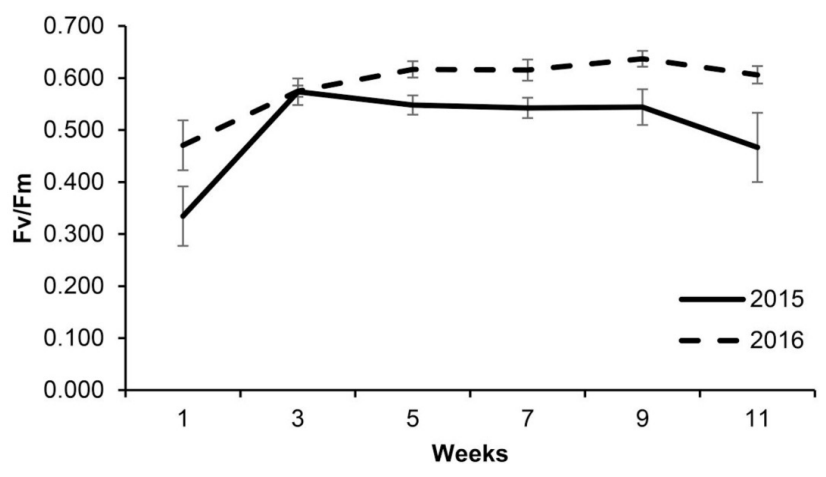

Fig. 6. Changes of maximum quantum efficiency of PSII $\left(\mathrm{F}_{\mathrm{v}} /\right.$ $\mathrm{F}_{\mathrm{m}}$ ) of Cladium mariscus in habitat $7210^{*}$ Calcareous fens with Cladium mariscus and species of the Caricion davallianae from June till middle of August in 2015 and 2016.

varies from $75 \mathrm{~cm}$ to $2 \mathrm{~m}$ (Mossberg, Stenberg 1992). The phenomenon of shorter generative shoots can be explained by stand age as shoots of establishing stands of clonal plants are smaller (McClintock, Waterway 1993). In the studied population, significant difference in height of generative shoots between years was not observed and there was significant difference in shoot density.

It is known that in unfavourable environmental conditions generative shoots in C. mariscus do not develop (Conway 1936) or only a few are formed (Bernard et al. 1985). In our study the number of C. mariscus generative shoots significantly differed between years, which can be explained by dry September and October and cool October in 2015 (Fig. 4). In that year October was the driest in the observation history of Latvia. Furthermore, it was also cool month, when temperature fell below $0{ }^{\circ} \mathrm{C}$ in 12 nights. Underground parts of $C$. mariscus are sensitive to frost but a sufficient water level can protect $C$. mariscus from impact of this factor (Conway 1938). In the studied habitat October was dry in 2015 (Fig. 4) and the generative shoot apex was not protected from low air temperature, which is the most likely reason why shoot apexes of generative shoots died, and, as a result, the number of generative shoots in the following vegetation season decreased.

Effect of water level on growth of the wetland species C. mariscus as is well-known, but the optimal water level in the studied habitat remains unclear. It is known that C. mariscus thrives in water with depths 5 to $25 \mathrm{~cm}$ in marshes of Greece (Theocharopoulos et al. 2006) and in a lake in North-Eastern Poland C. mariscus was submerged to a depth of 10 to $30 \mathrm{~cm}$ (Namura-Ochalska 2005). Chlorophyll $a$ fluorescence parameter $\mathrm{F}_{\mathrm{v}} / \mathrm{F}_{\mathrm{m}}$ has been used as a physiological marker to estimate plant response to environmental factors like waterlogging or flooding, drought, and temperature, but the results are contradictory and species-specific (Guo, Tan 2015) as well as experimental design-specific. In field experiments with Typha domingensis Pers., which grows together with 
Cladium mariscus subsp. jamaicensis Kuk., it was shown that $\mathrm{F}_{\mathrm{v}} / \mathrm{F}_{\mathrm{m}}$ decreased with increased flooding levels (Chen et al. 2010). The authors concluded that flooding is a significant stress factor for $T$. domingensis. In contrast, in our study there was no correlation between C. mariscus $\mathrm{F}_{\mathrm{v}}$ / $\mathrm{F}_{\mathrm{m}}$ and habitat water level during summer 2015 and 2016. However, $\mathrm{F}_{\mathrm{v}} / \mathrm{F}_{\mathrm{m}}$ was significantly higher in 2016 when habitat water level was higher. This suggests that a water level more than five centimetres is optimal for growth of $C$. mariscus populations in habitat $7210^{*}$ Calcareous fens with Cladium mariscus and species of the Caricion davallianae. There was no correlation between $\mathrm{F}_{\mathrm{v}} / \mathrm{F}_{\mathrm{m}}$ of $\mathrm{C}$. mariscus and two-week average temperature. In general, the average temperature of the warmest month was in the previously described tolerable temperature range for this species (Salmina 2004). Chlorophyll $a$ fluorescence was affected by phenological phase of $C$. mariscus. The rapid increase of $\mathrm{F}_{\mathrm{v}} / \mathrm{F}_{\mathrm{m}}$ in beginning of summer in both years might be related to the rapid growth of shoots. Further fluctuations were associated with gradual flowering and fruit ripening of C. mariscus. Decrease of $\mathrm{F}_{\mathrm{v}} / \mathrm{F}_{\mathrm{m}}$ was observed only during C. mariscus generative shoot senescence.

In conclusion, immediate effect of temperature or habitat water level changes on generative shoot growth were not observed. However, two-season measurements of $\mathrm{F}_{\mathrm{v}} / \mathrm{F}_{\mathrm{m}}$ showed that C. mariscus is adapted to a high habitat water level and might be sensitive to habitat water level fluctuation, when water level falls below $5 \mathrm{~cm}$. On the north-eastern limit of its distribution range, the number of generative shoots of $C$. mariscus in the next vegetation season is affected by previous autumn drought and temperature below $0{ }^{\circ} \mathrm{C}$.

\section{Acknowledgements}

The research has been supported by the National Research Programme 2014-2017 "EVIDEnT" (Agreement No. 10-4/VPP2/19).

\section{References}

Āboliṇa A. 2001. List of Bryophytes of Latvia. Latvijas Vegetācija. 3: 47-87. /in Latvian/

Atherton I., Bosanquet S., Lawley M. (eds.) 2010. Mosses and Liverworts of Britain and Ireland - a Field Guide. Latimer Trend \& Co. Ltd., Plymouth. 856 p.

Auniņa L. 2013. 7210* Calcareous fens with Cladium mariscus. In: Auniņš A. (ed.) European Union Protected Habitats in Latvia. Interpretation Manual. Latvijas Dabas fonds, Vides un reg̣ionālās attīstības ministrija, Rīga.pp. 234-236. /in Latvian/

Bernard J., Seischab F., Jacoby G. 1985. Life history and production of above- and belowground structures of Cladium mariscoides (Muhl.) Torr. in a western New York fen. Bull. Torrey Bot. Club 112: 288-294.

Burkill H. 2000. The Useful Plants of West Tropical Africa. Royal Botanic Gardens, Kew, Richmond. 686 p.

Buczek A. 2005. Habitat conditions, ecology, resources and protection of saw sedge Cladium mariscus (L.) Pohl in Lublin
Macroregion. Acta Agrophys. 9: 1-127./in Polish/

Chen H., Zamorano M. F., Ivanoff D. 2010. Effect of flooding depth on growth, biomass, photosynthesis, and chlorophyll fluorescence of Typha domingensis. Wetlands 30: 957-965.

Conway V. 1936. Studies in the autecology of Cladium mariscus R.Br. 1. Structure and development. New Phytol. 35: 177-204.

Conway V. 1938. Studies in autoecology of Cladium mariscus. New Phytol. 37: 312-327.

Conway V. 1940. Growth rates and water loss in Cladium mariscus R.Br. Ann. Bot. 4: 151-164.

Cronk J.K., Fennessy M.S. 2001. Wetland Plants: Biology and Ecology. CRC Press, Boca Raton. 462 p.

Doren R., Armentano T., Whiteaker L., Jones R. 1997. Marsh vegetation patterns and soil phosphorous characteristics in the Everglades ecosystem. Aquat. Bot. 56: 145-163.

Eglite Z. 2003. Cladium mariscus (L.) Pohl. In: Andrushaitis G. (ed.) Red Data Book of Latvia. Rare and Threatened Plants and Animals. Institute of Biology of University of Latvia, Riga. pp. 520-521. /in Latvian/

Guo Y., Tan J. 2015. Recent advances in the application of chlorophyll $a$ fluorescence from photosystem II. Photochem. Photobiol. 91: 1-14.

Jalas J., Okko V. 1951. Botanical and geological analysis of Cladium mariscus station in Joroinen. Arch. Soc. Zool. Bot. Fennicae 5: 82-101.

Kalaji H. M., Jajoo A., Oukarroum A., Brestic M., Zivcak M., Samborska I. A., Cetner M.D., Łukasik I., Goltsev V., Ladle R. J. 2016. Chlorophyll $a$ fluorescence as a tool to monitor physiological status of plants under abiotic stress conditions. Acta Physiol. Plant. 38: 1-11.

Kalaji H.M., Schansker G., Brestic M., Bussotti F., Calatayud A., Ferroni L., Goltsev V., Guidi L., Jajoo A., Li P., Losciale P., Mishra V.K., Misra A.N., Nebauer S.G., Pancaldi S., Penella C., Pollastrini M., Suresh K., Tambussi E., Yanniccari M., Zivcak M., Cetner M.D., Samborska I.A., Stirbet A., Olsovska K., Kunderlikova K., Shelonzek H., Rusinowski S., Bąba W. 2017. Frequently asked questions about chlorophyll fluorescence, the sequel. Photosynth. Res. 132: 1-54.

Kḷavinšs M., Kokorīte I., Rodinovs V., Jankevica M. 2014. Past human impact and pollutant loading reconstruction in Lake Engure as a tool for lake basin management. Proc. Latvian Acad. Sci. Section B 68: 31-37.

Kuusk V., Tabaka L., Jankevičiene R. (eds.) 2003. Flora of the Baltic Countries, III. Estonian Academy of Sciences Institute of Zoology and Botany, Tartu. 375 p.

Maxwell K., Johnson G.N. 2000. Chlorophyll fluorescence - a practical guide. J. Exp. Bot. 51: 659-668.

McClintock K., Waterway M. 1993. Patterns of allozyme variation and clonal diversity in Carex lasiocarpa and C. pellita (Cyperaceae). Am. J. Bot. 80: 1251-1263.

Meyerson A., Cronin J., Pyšek P. 2016. Phragmites australis as a model organism for studying plant invasions. Biol. Invasions 18: 2421-2431.

Moosberg B., Stenberg L. 1992. The Nordic Flora. W\&W Turnhout. 696 p./in Swedish/

Namura-Ochalska A. 2005. Contribution the characteristic of Cladium mariscus (L.) Pohl population in the initial zone of floating mat on a oligo-humotrophic Lake in the NorthEastern Poland. Acta Soc. Bot. Pol. 74: 167-173.

Roze D., Jakobsone G., Megre D., Belogrudova I., Karlovska A. 2014. Survival of Liparis loeselii (L.) Rich. as an early 
successional species in Engure region described based on ecological peculiarities during the annual cycle. Proc. Latvian Acad. Sci. Section B 68: 93-100.

Saltmarsh A., Mauchamp A., Rambal S. 2006. Contrasted effects of water limitation on leaf functions and growth of two emergent co-occurring plant species Cladium mariscus and Phragmites australis. Aquat. Bot. 84: 191-198.

Salmina L. 2003. The Cladium mariscus (L.) Pohl community in Latvia. Acta Univ. Latv. 654: 23-37.
Salmina L. 2004. Factors influencing distribution of Cladium mariscus in Latvia. Ann. Bot. Fenn. 41: 367-371.

Theocharopoulos M., Georgiadis T., Dimitrellos G., Chochliouros S., Tiniakou A. 2006. Vegetation types with Cladium mariscus (Cyperaceae) in Greece. Wildenowia 36: 247-256.

Vaughan G. 2012. Cladium mariscus (L.) Pohl. In: Brink M., Achigan-Dako E. (eds.) Fibres. Ponsen \& Looijen, Wageningen. pp. 85-88. 